\title{
Effects of Physically Effective Fiber on Chewing Activity and Ruminal pH of Dairy Cows Fed Diets Based on Barley Silage ${ }^{1}$
}

\author{
W. Z. Yang and K. A. Beauchemin ${ }^{2}$ \\ Agriculture and Agri-Food Canada, Research Centre, Lethbridge, AB, Canada T1J 4B1
}

\begin{abstract}
The objective of this study was to investigate the effects of physically effective neutral detergent fiber (peNDF) content of dairy cow diets containing barley silage as the sole forage source on feed intake, chewing activity, and ruminal $\mathrm{pH}$. The experiment was designed as a replicated $3 \times 3$ Latin square using 6 lactating dairy cows with ruminal cannulas. Cows were offered 1 of 3 diets (high, medium, and low peNDF) obtained using barley silage that varied in particle length: long (theoretical cut length of $9.5 \mathrm{~mm}$ ), medium (equal proportions of long and fine silages), and fine (theoretical cut length of $4.8 \mathrm{~mm}$ ). The peNDF contents were determined using the Penn State Particle Separator and were $13.8,11.8$, and $10.5 \%$, for the high, medium, and low diets, respectively. The physical effectiveness factors (defined as proportion retained on 19- and 8-mm screens) for the long and fine silages were 0.84 and 0.68 , respectively. Increased forage particle size increased intake of peNDF but did not affect intake of DM and NDF. Ruminating and total chewing time were linearly increased with increasing dietary peNDF. Mean ruminal $\mathrm{pH}$, area between the curve and a horizontal line drawn at $\mathrm{pH} 5.8$ or 5.5 , and time that $\mathrm{pH}$ was below 5.8 or 5.5 were not affected by peNDF content. Intake of peNDF was not correlated to any chewing activity but proportion of long particles on the 19-mm sieve tended to be correlated to ruminating chews $(r=0.36)$ and ruminating time $(\mathrm{r}=0.36)$. These results indicate that increasing the peNDF content of diets increases chewing time. However, increased chewing time does not always improve ruminal $\mathrm{pH}$ status. Increasing chewing time and thus increasing salivary secretion may not fully overcome the effects of feed digestion and the production of fermentation acids that lower rumen $\mathrm{pH}$. The results suggest that dietary peNDF and fermentable $\mathrm{OM}$ intake are critical in regulating rumen $\mathrm{pH}$. Dietary particle size, expressed as peNDF, was a reliable indication of chewing activity.
\end{abstract}

Received May 16, 2005.

Accepted August 30, 2005.

${ }^{1}$ Contribution number (387) 05032.

${ }^{2}$ Corresponding author: beauchemin@agr.gc.ca
Key words: physically effective neutral detergent fiber, chewing, rumen $\mathrm{pH}$, dairy cow

\section{INTRODUCTION}

Subacute ruminal acidosis (SARA) is a common and economically important metabolic disorder in dairy cattle (Nocek, 1997). Ruminal acidosis occurs when the $\mathrm{pH}$ in the rumen declines below optimum for fiber digestion by the rumen bacteria (Beauchemin, 2000). Low ruminal $\mathrm{pH}$ is the result of an accumulation of VFA due to feeding diets containing high proportions of fermentable concentrate and forage with low physically effective fiber (peNDF). Although these types of diets maximize milk production, they also increase the incidence of SARA. Subacute acidosis can reduce fiber digestion and cause inconsistent feed intake, diarrhea, low milk fat, laminitis, and other health disorders (Nocek, 1997). The economical losses from SARA are attributed not only to health problems, but also to increased feed costs due to poor fiber digestion and lower feed efficiency.

Fermentation acids in the rumen are mainly removed either by absorption through the ruminal wall or through neutralization by salivary and other buffers. It is estimated that salivary buffers account for about 30 to $40 \%$ of the neutralization of fermentation acids in the rumen (Allen, 1997). Salivary secretion increases when dairy cows chew during eating and ruminating time (Maekawa et al., 2002). Hence, it is usually assumed that increasing chewing time through manipulating dietary particle size improves ruminal $\mathrm{pH}$ status and thus potentially reduces the risk of ruminal acidosis (Yang et al., 2001; Krause et al., 2002).

A number of systems that predict the amount of chewing of various feeds or the effectiveness of feeds to maintain milk fat content have been proposed for use in dairy ration formulation. Of the proposed fiber systems, the concept of peNDF proposed by Mertens (1997) is most closely related to ruminal $\mathrm{pH}$ because it is a measure that reflects the physical characteristics of fiber, mainly particle size, and its ability to stimulate chewing and saliva buffering in the rumen. The peNDF of a feed is the product of its physical effectiveness factor (pef) and NDF concentration. However, the NRC (2001) pro- 
vides no recommendations for inclusion of peNDF because of the lack of a standard, validated technique to quantify the physically effective properties of fiber in a diet. Although a number of studies have been conducted in recent years to determine the effects of dietary peNDF on feed intake, chewing time, and ruminal $\mathrm{pH}$ (Yang et al., 2001; Krause et al., 2002; Beauchemin et al., 2003; Kononoff et al., 2003; Plaizier, 2004), most have been conducted using corn grain-based diets. Barley grain contains more NDF than corn grain, and barley starch is more rapidly fermentable than corn starch (Yang et al., 1997). The requirements of dietary particle size by dairy cows fed barley grain-based diets can be different from those of cows fed corn grain-based diets. In addition, the Penn State Particle Separator (PSPS) is a quick and cost-effective method to estimate forage and TMR particle size and was constructed for particle size determination of feeds on-farm (Lammers et al., 1996). Although the apparatus has been widely accepted, few studies have attempted to investigate effects of forage particle size measured by the PSPS for barley grain based-diets. The objectives of the present study were to determine the effect of particle size of barley silage (BS) when fed in combination with barley grain on feed intake, chewing activity, ruminal $\mathrm{pH}$, and fermentation in lactating dairy cows. The recent addition of a 1.18-mm screen to the PSPS results in the retention of almost the entire sample for haylages and corn silages (Kononoff and Heinrichs, 2003a), and thus, overestimates the proportion of particles $>1.18 \mathrm{~mm}$. Hence, the original PSPS was used to measure particle size distribution of the BS and TMR. The effects on site and extent of digestion, microbial protein synthesis, and milk yield, and composition of lactating dairy cows were measured and reported separately (W. Z. Yang and K. A. Beauchemin, unpublished data).

\section{MATERIALS AND METHODS}

\section{Barley Silage}

Whole plant barley (Westford, 6-row hooded hay barley, Bozeman, MT) was harvested at a moisture content of $65 \%$ from one field and ensiled on the same day in a large silo bag (200 tonne capacity) 2 mo before being used. A forage harvester (model 6910, John Deere, West Bend, WI), equipped with a 37 -tooth sprocket and 8 knives, was used to obtain silage chopped at a theoretical cut length (TCL) of 9.5 and $4.8 \mathrm{~mm}$ for long and short cut, respectively. Two kilograms of each BS (long and short) were obtained weekly and immediately subdivided into 3 portions for determining particle size, DM content, and chemical composition, respectively
Table 1. Chemical composition and particle size distribution of barley silage measured using the Penn State Particle Separator

\begin{tabular}{|c|c|c|c|c|}
\hline \multirow[b]{2}{*}{ Item } & \multicolumn{2}{|c|}{ Barley silage } & \multirow[b]{2}{*}{ SE } & \multirow[b]{2}{*}{$\begin{array}{l}\text { Effect } \\
P<\end{array}$} \\
\hline & $\begin{array}{l}\text { Long } \\
\text { cut }\end{array}$ & $\begin{array}{l}\text { Short } \\
\text { cut }\end{array}$ & & \\
\hline \multicolumn{5}{|l|}{ Chemical composition } \\
\hline $\mathrm{DM}, \%$ & 39.8 & 37.9 & 1.3 & 0.05 \\
\hline $\mathrm{OM}, \% \mathrm{DM}$ & 88.1 & 89.8 & 1.0 & NS \\
\hline NDF, \% DM & 43.2 & 42.6 & 0.5 & 0.05 \\
\hline $\mathrm{ADF}, \% \mathrm{DM}$ & 24.3 & 23.7 & 0.7 & NS \\
\hline Starch, \% DM & 21.6 & 21.9 & 0.8 & NS \\
\hline $\mathrm{N}, \% \mathrm{DM}$ & 2.35 & 2.30 & 0.03 & 0.10 \\
\hline \multicolumn{5}{|c|}{$\begin{array}{l}\text { Physical determination }{ }^{1} \\
\text { \% DM retained on sieves }\end{array}$} \\
\hline $19.0 \mathrm{~mm}$ & 4.1 & 1.5 & 0.1 & 0.01 \\
\hline $8.0 \mathrm{~mm}$ & 80.0 & 66.9 & 1.6 & 0.01 \\
\hline Pan & 15.9 & 31.6 & 1.6 & 0.01 \\
\hline pef & 0.84 & 0.68 & 0.02 & 0.01 \\
\hline peNDF, $\%$ & 36.4 & 29.1 & 1.2 & 0.01 \\
\hline \multicolumn{5}{|l|}{ Fermentation ${ }^{2}$} \\
\hline $\mathrm{pH}$ & 3.91 & 3.92 & - & - \\
\hline Acetic acid, \% DM & 1.12 & 1.03 & - & - \\
\hline Propionic acid, \% DM & $<0.01$ & $<0.01$ & - & - \\
\hline Butyric acid, \% DM & $<0.01$ & $<0.01$ & - & - \\
\hline \multicolumn{5}{|l|}{ Lactic acid } \\
\hline$\% \mathrm{DM}$ & 7.3 & 6.0 & - & - \\
\hline$\%$ total acid & 86.7 & 85.4 & - & - \\
\hline Ammonia, \% DM & 0.6 & 0.6 & - & - \\
\hline
\end{tabular}

${ }^{1}$ Particle size distribution of barley silage was measured using Penn State Particle Separator (Lammers et al., 1996); the physical effectiveness factor (pef) was determined as the proportion of particles retained by both sieves; and peNDF (physically effective NDF) was measured as the NDF content of the silage multiplied by the pef.

${ }^{2}$ Fermentation parameters were determined by Cumberland Valley Analytical Service, Inc. (Maugansville, MD) using a single representative sample.

(Table 1). Particle size distribution of the silage was determined using the PSPS (Lammers et al., 1996) containing 2 sieves (19 and $8 \mathrm{~mm}$ ) and a pan. The DM content was determined by oven drying at $55^{\circ} \mathrm{C}$ for 48 h. The third portion of each sample was composited by experimental period and retained for determination of chemical composition. Fermentation parameters of the silage as sampled from the silo midway through the experiment were determined commercially by Cumberland Valley Analytical Service, Inc. (Maugansville, $\mathrm{MD}$ ).

\section{Cows and Diets}

Six lactating Holstein cows were used in an experiment to investigate effects of peNDF content of BSbased diets on feed intake, eating patterns, diurnal variation of chewing activity, ruminal $\mathrm{pH}$, and characteristics of ruminal fermentation. The cows were fitted with ruminal cannulas, and averaged $652 \pm 118 \mathrm{~kg}$ of BW and $189 \pm 39$ DIM at the start of the experiment. Cows were randomly assigned to a replicated $3 \times 3$ Latin square with 2 different squares for balancing carryover 
Table 2. Ingredients and chemical composition of the diets differing in physically effective fiber (peNDF) content

\begin{tabular}{lccccc}
\hline & \multicolumn{3}{c}{ Dietary peNDF } & & Effect \\
\cline { 2 - 4 } & High & Medium & Low & SE & Linear \\
\hline Ingredients, \% DM & & & & & \\
Barley silage, long cut & 46.6 & 23.3 & - & - & - \\
Barley silage, short cut & - & 23.3 & 46.6 & - & - \\
Barley grain, steam-rolled & 37.4 & 37.4 & 37.4 & - & - \\
Corn gluten meal & 3.01 & 3.01 & 3.01 & - & - \\
Heat-treated canola meal (Alberta Gold) ${ }^{2}$ & 5.01 & 5.01 & 5.01 & - & - \\
Soybean meal & 4.51 & 4.51 & 4.51 & - & - \\
Beet molasses & 0.50 & 0.50 & 0.50 & - & - \\
Calcium carbonate & 0.70 & 0.70 & 0.70 & - & - \\
Dicalcium phosphorus & 0.45 & 0.45 & 0.45 & - & - \\
Vitamin-mineral mix & & & & - \\
Canola oil & 1.15 & 1.15 & 1.15 & - & - \\
Binding agent (Aka) ${ }^{4}$ & 0.50 & 0.50 & 0.50 & - & - \\
Chemical composition & 0.17 & 0.17 & 0.17 & - & \\
DM, \% & & & & & NS \\
CP,\% DM & 53.0 & 52.9 & 52.4 & 0.2 & NS \\
NDF, \% DM & 17.7 & 17.5 & 17.4 & 0.6 & NS \\
NDF from forages, \% DM & 33.4 & 32.1 & 32.1 & 0.9 & NS \\
ADF, \% DM & 20.2 & 20.0 & 19.8 & 0.2 & NS \\
Starch, \% DM & 15.3 & 15.5 & 15.6 & 0.3 & NS \\
NE, Mcal/kg & 30.8 & 31.5 & 31.3 & 0.4 & NS
\end{tabular}

${ }^{1}$ Chemical composition of barley grain (DM basis) was $90.2,23.6,6.8$, and $11.3 \%$ for OM, NDF, ADF, and $\mathrm{CP}$, respectively.

${ }^{2}$ Alberta Gold, Canbra Foods, Ltd., Lethbridge, AB, Canada.

${ }^{3}$ Contained 51.97\% NaCl; 35.98\% Dynamate (Pitman Moore, Inc., Mundelein, IL; $18 \% \mathrm{~K} ; 11 \% \mathrm{Mg} ; 22 \%$ $\mathrm{S} ; 1,000 \mathrm{mg} \mathrm{Fe} / \mathrm{kg}) ; 2 \% \mathrm{ZnSO}_{4} \cdot \mathrm{H}_{2} \mathrm{O} ; 2.4 \% \mathrm{MnSO}_{4} \cdot 4 \mathrm{H}_{2} \mathrm{O} ; 0.01 \% \mathrm{CoSO}_{4} \cdot 6 \mathrm{H}_{2} \mathrm{O} ; 0.009 \% \mathrm{Na}_{2} \mathrm{SeO}_{3} ; 0.012 \%$ ethylenediamine dihydroiodide; $0.8 \% \mathrm{CuSO}_{4} \cdot 5 \mathrm{H}_{2} \mathrm{O} ; 680,000 \mathrm{IU} / \mathrm{kg}$ of vitamin A; $160,000 \mathrm{IU} / \mathrm{kg}$ of vitamin $\mathrm{D}$; and 2,000 IU/kg of vitamin E.

${ }^{4}$ Aka, Bear River Zeolite of Canada Corp., Lethbridge, AB, Canada.

${ }^{5} \mathrm{NS}=P>0.15$.

effects. The 2 squares with 3 cows in each square were simultaneously conducted. The ruminal cannulas measured $10 \mathrm{~cm}$ in diameter and were constructed of soft plastic (Bar Diamond, Parma, ID). Cows were housed in individual tie stalls and offered a TMR 3 times daily at 0600,1500 , and $1800 \mathrm{~h}$ for ad libitum intake to allow for approximately $10 \%$ refusal. Cows were cared for according to the Canadian Council on Animal Care Guidelines (Ottawa, ON, Canada).

Cows were offered 1 of 3 diets, which were chemically very similar with approximately $53 \%$ concentrate and $47 \%$ BS (Table 2) but differed in peNDF concentration: high, medium, and low. The 3 dietary peNDF levels were obtained using BS differing in particle length: $100 \%$ long silage (high), 50\% long silage $+50 \%$ short silage (medium), and 100\% short silage (low). The diets were formulated using the Cornell-Penn-Miner System (CPM Dairy, Version 2.23, Cornell University, Ithaca, NY; University of Pennsylvania, Kennett Square, PA; and William H. Miner Agricultural Research Institute, Chazy, NY) to supply adequate metabolizable energy and metabolizable protein for a $600-\mathrm{kg}$ cow producing $30 \mathrm{~kg} / \mathrm{d}$ of milk with $3.5 \%$ fat and $3.2 \%$ protein. Each period consisted of $11 \mathrm{~d}$ of adaptation to diets and 10 d of experimental measurements.

Feed offered and orts were measured and recorded daily during the last $10 \mathrm{~d}$ of the period to calculate feed intake. Feed samples including BS and TMR were collected once weekly, and orts were collected daily and composited weekly for particle distribution analysis and DM determination on a weekly basis, and then composited by period. The composited samples were dried in an oven at $55^{\circ} \mathrm{C}$ for $48 \mathrm{~h}$ and then ground through a 1-mm diameter screen (standard model 4, Arthur Thomas Co., Philadelphia, PA) for analysis of $\mathrm{OM}, \mathrm{NDF}, \mathrm{ADF}$, starch, and CP.

\section{Meal Duration and Eating Behavior}

Eating behavior was monitored for $72 \mathrm{~h}$, during which chewing was also monitored. Feed mangers were attached to load cells (Omega Engineering Inc., Stamford, CT), which were connected to a computer. The load cells monitored feed weight continually and an average weight was obtained every $11 \mathrm{~s}$ and stored using Collect software (Labtronics, Inc., Guelph, ON, 
Canada). Feeding activity was separated into meals using a meal criterion of $27 \mathrm{~min}$ as outlined by DeVries et al. (2003). The meal criterion was used as the minimum interval between 2 meals for determining meal frequency and meal duration. A meal was defined as eating activity greater than $30 \mathrm{~s}$ and more than $300 \mathrm{~g}$ of feed being removed from the feeder. Rate of DMI was calculated as the ratio of DM ingested and duration of the meal.

\section{Chewing Behavior}

Cows were fitted with leather halters for $72 \mathrm{~h}$ that were equipped to measure jaw movements. Each halter contained a piezo disk (Edmund Scientific Company, Barrington, NJ), which was inserted within the halter and positioned under the jaw. Chewing action places stress on the disk generating an electrical signal, which is then processed and counted as a single jaw movement. A datalogger (Campbell Scientific, Inc., Logan, UT) was used to receive the output signal from each cow. The number of jaw movements was summed each minute and stored until retrieval. The jaw movements were then designated as eating or ruminating chews. Jaw movements were considered as eating chews if they occurred during a meal (i.e., duration of the eating activity was greater than $30 \mathrm{~s}$ and more than $300 \mathrm{~g}$ of feed was removed from the feeder during the meal). Jaw movements were designated as ruminating chews if they did not occur during a meal and rate of chewing exceeded 30 chews $/ \mathrm{min}$. All other jaw movements were considered associated with licking, drinking, and grooming and were not included in the eating or ruminating categories. Total number of chews was calculated as the sum of eating and ruminating chews. Total time spent eating, ruminating, and chewing (eating + ruminating) was based on the duration of chewing activity. In the event of electrical or mechanical damage, corrupted data were deleted and measurements were made later.

\section{Ruminal $\mathrm{pH}$ and Fermentation}

Ruminal $\mathrm{pH}$ was monitored for $72 \mathrm{~h}$ concurrent with measurements of chewing and eating behavior during $\mathrm{d} 12$ to 15 of the period. The $\mathrm{pH}$ was measured using an industrial electrode (model S650-CDHF, Sensorex, Garden Grove, CA) linked to a $\mathrm{pH}$ controller (model PHCN-37, Omega Engineering Inc.). The electrodes were suspended approximately $60 \mathrm{~cm}$ in the rumen using a cable anchored to the ruminal cannula plug. The electrodes were weighted down to ensure submersion within the rumen contents. This indwelling, continuous ruminal $\mathrm{pH}$ measurement device resulted in values that were about 0.05 units lower than manual measurements of $\mathrm{pH}$ taken from the same location within the rumen (K. Beauchemin, unpublished data). The electrodes were covered with a perforated guard to prevent them from coming into direct contact with the rumen wall. The $\mathrm{pH}$ electrodes were removed from the rumen for 20 min daily between 1400 and $1430 \mathrm{~h}$ for calibration using pH 4.0 and 7.0 standards. Continuous measurements from the indwelling probe were sent to a datalogger (Campbell Scientific, Inc.) every $5 \mathrm{~s}$ and averaged every 5 min. Ruminal $\mathrm{pH}$ data were summarized daily for each cow as mean $\mathrm{pH}$, minimum $\mathrm{pH}$, maximum $\mathrm{pH}$, area under the $\mathrm{pH}$ curve, area between the observed $\mathrm{pH}$ and a line drawn at $\mathrm{pH} 5.8$ or 5.5 , and time (h) under $\mathrm{pH} 5.8$ or 5.5 . The maximum and minimum $\mathrm{pH}$ values for each day and each cow were obtained from the raw input data using PROC MEANS (SAS Institute, 1996). The area was calculated by adding the absolute value of negative deviations in $\mathrm{pH}$ from 5.5 or 5.8 for each 15-min interval. A ruminal pH of 5.8 was chosen as a benchmark for subacute acidosis because cellulolytic bacteria cannot grow below this $\mathrm{pH}$ (Russell and Wilson, 1996).

Ruminal fluid was collected on d 13 at 0900, 1200, and $1600 \mathrm{~h}$ from multiple sites in the rumen for VFA and $\mathrm{NH}_{3} \mathrm{~N}$ determination. Samples were immediately squeezed through 4 layers of cheesecloth with a mesh size of $250 \mu \mathrm{m}$. Five milliliters of filtrate was preserved by adding $1 \mathrm{~mL}$ of $25 \% \mathrm{HPO}_{3}$ to determine VFA, and $5 \mathrm{~mL}$ of filtrate was preserved by adding $1 \mathrm{~mL}$ of $1 \%$ $\mathrm{H}_{2} \mathrm{SO}_{4}$ to determine $\mathrm{NH}_{3} \mathrm{~N}$. The samples were subsequently stored frozen at $-20^{\circ} \mathrm{C}$ until analyzed.

\section{Chemical Analyses}

Feed DM was determined by oven drying at $55^{\circ} \mathrm{C}$ for $48 \mathrm{~h}$. Analytical DM content of the samples was determined by drying at $135^{\circ} \mathrm{C}$ for $3 \mathrm{~h}$ (AOAC, 1990). The OM content was calculated as the difference between DM and ash contents, with ash determined by combustion at $550^{\circ} \mathrm{C}$ for $6 \mathrm{~h}$. The NDF and ADF contents were determined using the methods described by Van Soest et al. (1991) with amylase and sodium sulfite used in the NDF procedure. Starch was determined by enzymatic hydrolysis of $\alpha$-linked glucose polymers as described by Rode et al. (1999). Content of $\mathrm{N}$ in the samples was determined by flash combustion, chromatographic separation, and thermal conductivity detection (Carlo Erba Instruments, Milan, Italy). Ruminal VFA were separated and quantified by gas chromatography (Varian 3700; Varian Specialties Ltd., Brockville, ON) using a 15-m (0.53-mm i.d.) fused silica column (DB-FFAP column; J\&W Scientific, Folsom, CA). Ammonia content of ruminal samples was deter- 
mined using the method described by Weatherburn (1967) modified to use a plate reader. Particle size distributions of BS, TMR, and orts were determined using the PSPS (Lammers et al., 1996). Physical effectiveness factors for silage, TMR, and orts were calculated as the sum of the proportions of the materials retained on the 19- and 8-mm sieves of the PSPS. The peNDF of the diets was determined by multiplying the pef of the TMR by the NDF content (DM basis) of the diet.

\section{Statistical Analyses}

Data were analyzed using the mixed model procedure of SAS (Proc Mixed; SAS Institute, 1996) to account for effects of square, period within square, cow within square, and treatment. The treatment was considered a fixed effect; square, period within square, and cow within square were considered random effects. Estimation method was REML and the degrees of freedom method was Kenward-Rogers. Data for meals, chewing activity, and ruminal $\mathrm{pH}$ were summarized by day and then analyzed using the same mixed model but with day included as a repeated measure and using compound symmetry. Similarly, data for VFA and ammonia were analyzed by sampling time using repeated measures techniques. Data for particle distribution, pef, and peNDF of forages and diets were averaged by period and analyzed by including particle length as a fixed effect and period as a random effect. Linear and quadratic orthogonal contrasts were tested using the CONTRAST statement of SAS. Pearson correlation coefficients were estimated using the CORR procedure of SAS. Effects of the factors were declared significant at $P<0.05$ unless otherwise noted and trends were discussed at $P<0.15$.

\section{RESULTS}

\section{Feed Particle Length and Effective Fiber}

Chemical composition was similar for long- and shortcut BS, although small significant differences in DM and NDF contents were observed (Table 1). Particle distribution of BS was significantly affected by TCL, as anticipated. A smaller proportion of particles was retained on both sieves of the PSPS for short- compared with long-cut BS, and consequently, pef was reduced by $20 \%$ when TCL was reduced from 9.5 to $4.8 \mathrm{~mm}$.

Chemical composition of the TMR offered (high, medium, and low peNDF) was not different because the concentrate formulation was identical and the long and short BS had similar chemical compositions (Table 2). Proportion of particles on the first and second sieves, and pef of the original TMR linearly decreased with increasing proportion of short-cut BS in the diets (Table
3 ). The pef of the TMR offered (range of 0.33 to 0.41) was significantly smaller than that of the BS (range of 68 to $84 \%$ ) because $53 \%$ of TMR was concentrate that almost entirely passed through the $8-\mathrm{mm}$ sieve. The peNDF value linearly decreased with decreasing particle length and reflected the pef of the TMR.

Particle size distributions of orts differed from those of the TMR offered for the high and medium peNDF diets, but not for the low peNDF diet. The pef of the orts were reduced by 20 and 16\% for the high and medium diets, respectively, compared with the diets offered. However, only the pef of the high peNDF diet consumed, after adjustment for the pef of the orts, was different from the TMR offered. The particle size distribution and pef of the medium and low peNDF diets were not affected by the adjustment for the pef of orts.

\section{Intake, Chewing Activity, and Meal Patterns}

Intakes of DM and NDF were not affected by peNDF level of the diets (Table 4). Intake of peNDF followed the same trend as pef contents of the diets and linearly decreased with smaller particle size of the silage. Similarly, intakes of particles on both sieves ( $>19$ and $>8$ $\mathrm{mm}$ ) linearly decreased and reflected the proportion of these particles in the diets.

Changing the peNDF content of the diet did not affect eating activity expressed either as number of eating chews (chews/d) or as eating time (Table 5). Although number of ruminating chews was not affected, total ruminating time ( $\mathrm{min} / \mathrm{d})$ was linearly decreased and ruminating time per unit of DM or NDF intake tended $(P<0.12)$ to linearly decrease with reduced peNDF content of the diets. As a result, daily number of chews (eating + ruminating chews) was similar among the treatments, whereas daily chewing time $(\mathrm{min} / \mathrm{d})$ and chewing time per unit of DM or NDF intake were linearly decreased with decreasing peNDF levels in the diets. In other words, daily chewing time was reduced by about 11 or $97 \mathrm{~min}$ when high peNDF diet was replaced by medium or low peNDF diets, respectively. The pattern of diurnal eating activity of cows was similar among the treatments (Figure 1a). The highest eating activity was observed after the $1500 \mathrm{~h}$ feeding followed by activity at the $0600 \mathrm{~h}$ feeding. However, cows did not show an eating peak at the $1800 \mathrm{~h}$ feeding due to high eating activity between 1500 and $1700 \mathrm{~h}$.

In general, meal patterns including number of meals per day, duration of single meals, average meal size, and intake rate per min were not affected by dietary peNDF level (Table 5). Diurnal variation in amount of feed consumed by cows generally followed the pattern of eating time (Figure 1b). The highest amount of feed consumed at any one time occurred for cows fed the 
Table 3. Effects of reducing silage particle length on particle distribution, the physical effectiveness factor (pef), and physically effective fiber (peNDF) contents of the diets and orts

\begin{tabular}{|c|c|c|c|c|c|c|}
\hline & \multicolumn{3}{|c|}{ Dietary peNDF } & \multirow[b]{2}{*}{$\mathrm{SE}$} & \multicolumn{2}{|c|}{ Effects } \\
\hline & High & Medium & Low & & Linear & Quadratic \\
\hline \multicolumn{7}{|l|}{ TMR offered } \\
\hline \multicolumn{7}{|c|}{$\%$ DM retained on screens: } \\
\hline $19 \mathrm{~mm}$ & 2.0 & 1.4 & 0.7 & 0.1 & 0.01 & $\mathrm{NS}^{3}$ \\
\hline $8 \mathrm{~mm}$ & 39.2 & 35.6 & 32.0 & 1.2 & 0.01 & NS \\
\hline Pan & 58.8 & 63.1 & 67.4 & 0.9 & 0.01 & NS \\
\hline pef $^{1}$ & 0.41 & 0.37 & 0.33 & 0.01 & 0.01 & NS \\
\hline peNDF, ${ }^{2} \%$ of DM & 13.8 & 11.8 & 10.5 & 0.3 & 0.01 & NS \\
\hline \multicolumn{7}{|l|}{ Orts } \\
\hline \multicolumn{7}{|c|}{ \% DM retained on screens: } \\
\hline $19 \mathrm{~mm}$ & 0.9 & 0.7 & 0.5 & 0.2 & 0.15 & NS \\
\hline $8 \mathrm{~mm}$ & 31.7 & 30.6 & 27.8 & 3.0 & NS & NS \\
\hline Pan & 67.3 & 68.7 & 71.7 & 3.1 & NS & NS \\
\hline pef $^{1}$ & 0.33 & 0.31 & 0.28 & 0.03 & NS & NS \\
\hline peNDF $^{2}, \%$ of DM & 11.2 & 10.8 & 9.7 & 1.2 & NS & NS \\
\hline \multirow{2}{*}{\multicolumn{7}{|c|}{ TMR consumed (adjusted for particle size of orts) }} \\
\hline$\% \mathrm{DM}$ retained on & & & & & & \\
\hline $19 \mathrm{~mm}$ & 2.3 & 1.6 & 0.8 & 0.1 & 0.01 & NS \\
\hline $8 \mathrm{~mm}$ & 41.1 & 36.5 & 33.6 & 1.0 & 0.01 & NS \\
\hline Pan & 56.5 & 61.9 & 65.6 & 1.0 & 0.01 & NS \\
\hline pef $^{1}$ & 0.44 & 0.38 & 0.34 & 0.01 & 0.01 & NS \\
\hline peNDF $^{2}, \%$ of DM & 14.5 & 12.2 & 11.0 & 0.5 & 0.01 & NS \\
\hline
\end{tabular}

${ }^{1}$ pef determined as the proportion of particles retained by both sieves of the Penn State Particle Separator. ${ }^{2}$ peNDF measured as the NDF content of the TMR multiplied by the pef.

${ }^{3} \mathrm{NS}=P>0.15$.

medium peNDF diet at 0600 and $1500 \mathrm{~h}$ and corresponded to longer eating time in the same period (Figure 1a).

\section{Rumen $\mathrm{pH}$ and Fermentation}

Diurnal ruminal $\mathrm{pH}$ for all the treatments appeared to be highest just before the 0600 and $1500 \mathrm{~h}$ feedings (Figure 1c). Diurnal variation in ruminal $\mathrm{pH}$ was more apparent for cows fed medium or low peNDF diets than for cows fed the high peNDF diet. For example, hourly averaged ruminal $\mathrm{pH}$ declined from 5.9 to 5.4 for the medium peNDF diet, but only from 5.7 to 5.5 for the high peNDF diet between 1400 and 2100 h. Never- theless, mean $\mathrm{pH}$, area between the curve and a horizontal line at $\mathrm{pH} 5.8$ or 5.5 , and duration in which $\mathrm{pH}$ $<5.8$ or $\mathrm{pH}<5.5$ were not affected by peNDF contents of the diets (Table 6). The highest $\mathrm{pH}$ was 6.35 and the lowest 5.15, but no differences were observed among treatments.

Total concentration of VFA quadratically increased $(P<0.06)$ from 128 to $138 \mathrm{mM}$ with reducing peNDF content of the diets (Table 6). The same effect was observed for the molar proportion of butyrate $(P<0.11)$ and caproic acid, but no differences were observed for proportions of acetate and propionate. Furthermore, no differences in acetate to propionate ratio were observed among treatments. Ammonia concentration in the ru-

Table 4. Effects of reducing dietary physically effective fiber (peNDF) on feed intake of dairy cows

\begin{tabular}{|c|c|c|c|c|c|c|}
\hline \multirow[b]{2}{*}{ Item } & \multicolumn{3}{|c|}{ Dietary peNDF ${ }^{1}$} & \multirow[b]{2}{*}{$\mathrm{SE}$} & \multicolumn{2}{|c|}{ Effects } \\
\hline & High & Medium & Low & & Linear & Quadratic \\
\hline \multicolumn{7}{|l|}{ DMI } \\
\hline $\mathrm{kg} / \mathrm{d}$ & 19.4 & 20.8 & 19.6 & 2.2 & NS & NS \\
\hline$\%$ of BW & 2.9 & 3.1 & 2.9 & 0.2 & NS & NS \\
\hline NDF intake, $\mathrm{kg} / \mathrm{d}$ & 6.5 & 6.5 & 6.2 & 0.7 & NS & NS \\
\hline peNDF intake, $\mathrm{kg} / \mathrm{d}$ & 2.8 & 2.3 & 2.1 & 0.3 & 0.01 & NS \\
\hline \multicolumn{7}{|l|}{ Intake of particles, $\mathrm{kg} / \mathrm{d}$} \\
\hline$>19 \mathrm{~mm}$ & 0.5 & 0.3 & 0.2 & 0.02 & 0.01 & NS \\
\hline 19 to $8 \mathrm{~mm}$ & 8.0 & 6.9 & 6.5 & 0.6 & 0.10 & NS \\
\hline $\mathrm{BW}, \mathrm{kg}$ & 678 & 692 & 679 & 65 & NS & 0.14 \\
\hline
\end{tabular}

${ }^{1}$ peNDF measured as the NDF content of the TMR multiplied by the pef. NS $=P>0.15$. 
Table 5. Effects of reducing dietary physically effective fiber (peNDF) on chewing activity of dairy cows

\begin{tabular}{|c|c|c|c|c|c|c|}
\hline \multirow[b]{2}{*}{ Item } & \multicolumn{3}{|c|}{ Dietary peNDF } & \multirow[b]{2}{*}{$\mathrm{SE}$} & \multicolumn{2}{|c|}{ Effects } \\
\hline & High & Medium & Low & & Linear & Quadratic \\
\hline \multicolumn{7}{|l|}{ Eating } \\
\hline Chews/d & 11,591 & 12,299 & 11,452 & 2,130 & $\mathrm{NS}^{2}$ & NS \\
\hline Chews/kg of DM & 597 & 636 & 604 & 103 & NS & NS \\
\hline Chews/kg of NDF & 1,808 & 1,992 & 1,902 & 318 & NS & NS \\
\hline $\operatorname{Min} / \mathrm{d}$ & 279.6 & 272.1 & 259.4 & 27.1 & NS & NS \\
\hline $\mathrm{Min} / \mathrm{kg}$ of $\mathrm{DM}$ & 14.9 & 14.1 & 13.6 & 2.3 & NS & NS \\
\hline $\mathrm{Min} / \mathrm{kg}$ of $\mathrm{NDF}$ & 45.7 & 44.3 & 42.9 & 7.1 & NS & NS \\
\hline $\mathrm{Min} / \mathrm{kg}$ of peNDF${ }^{1}$ & 105.4 & 115.2 & 123.8 & 16.8 & NS & NS \\
\hline \multicolumn{7}{|l|}{ Ruminating } \\
\hline Chews/d & 27,121 & 30,068 & 25,472 & 3,320 & NS & NS \\
\hline Chews/kg of DM & 1,418 & 1,536 & 1,361 & 195 & NS & NS \\
\hline Chews/kg of NDF & 4,350 & 4,861 & 4,285 & 639 & NS & NS \\
\hline Min/d & 439.7 & 445.8 & 362.7 & 39.2 & 0.03 & 0.14 \\
\hline $\mathrm{Min} / \mathrm{kg}$ of DM & 23.2 & 22.8 & 18.8 & 2.2 & 0.10 & NS \\
\hline $\mathrm{Min} / \mathrm{kg}$ of $\mathrm{NDF}$ & 71.3 & 71.2 & 59.5 & 8.2 & 0.12 & NS \\
\hline $\mathrm{Min} / \mathrm{kg}$ of $\mathrm{peNDF}^{1}$ & 164.3 & 185.3 & 171.9 & 20.4 & NS & NS \\
\hline \multicolumn{7}{|l|}{ Total chewing } \\
\hline Chews/d & 38,711 & 42,490 & 36,924 & 5,090 & NS & NS \\
\hline Chews/kg of DM & 2,015 & 2,165 & 1,966 & 278 & NS & NS \\
\hline Chews/kg of NDF & 6,158 & 6836 & 6,187 & 899 & NS & NS \\
\hline $\operatorname{Min} / \mathrm{d}$ & 719.3 & 708.2 & 622.1 & 57.3 & 0.01 & 0.07 \\
\hline $\mathrm{Min} / \mathrm{kg}$ of $\mathrm{DM}$ & 38.2 & 36.4 & 32.5 & 3.6 & 0.03 & NS \\
\hline $\mathrm{Min} / \mathrm{kg}$ of $\mathrm{NDF}$ & 117.0 & 114.6 & 102.4 & 12.4 & 0.03 & NS \\
\hline $\mathrm{Min} / \mathrm{kg}$ of $\mathrm{peNDF}^{1}$ & 269.7 & 300.1 & 295.7 & 29.9 & 0.09 & NS \\
\hline \multicolumn{7}{|l|}{ Meal patterns } \\
\hline Meals/d & 8.8 & 9.2 & 8.5 & 0.6 & NS & NS \\
\hline Meal length, min/meal & 31.5 & 32.0 & 30.8 & 3.1 & NS & NS \\
\hline \multicolumn{7}{|l|}{ Meal size, kg } \\
\hline $\mathrm{DM}$ & 2.22 & 2.18 & 2.34 & 0.39 & NS & NS \\
\hline $\mathrm{NDF}$ & 0.73 & 0.69 & 0.74 & 0.12 & NS & NS \\
\hline peNDF & 0.32 & 0.26 & 0.25 & 0.05 & 0.04 & NS \\
\hline Intake rate, $\mathrm{g}$ of $\mathrm{DM} / \mathrm{min}$ & 72.4 & 75.5 & 77.9 & 12.5 & NS & NS \\
\hline
\end{tabular}

${ }^{1}$ peNDF measured as the NDF content of the TMR multiplied by the pef (Table 4).

${ }^{2} \mathrm{NS}=P>0.15$.

men quadratically increased from 8.5 to $11.0 \mathrm{~m} M$ with reducing peNDF content of the diets.

\section{DISCUSSION}

Particle size distribution of BS used in commercial dairy farms is extremely variable. Beauchemin and Rode (1998) measured the particle size of BS from 57 farms in Alberta, Canada, using the PSPS, and found that particle size distribution varied tremendously although all silages were harvested at a TCL of $9.5 \mathrm{~mm}$. An average of $10 \%$ of the particles (by weight) were retained on the $19-\mathrm{mm}$ sieve, but this value ranged from 2 to $42 \%$ across farms. The pef averaged 0.63 , and ranged from 0.46 to 0.85 . Similarly, other researchers (Kononoff et al., 2000; Einarson et al., 2004; Eun et al., 2004) reported that particle size distribution of BS was variable with particles on the $19-\mathrm{mm}$ sieve ranging from 5 to $11 \%$ and the pef ranging from 0.65 to 0.78 for BS harvested at $9.5 \mathrm{~mm}$. The results for the long BS used in the present experiment at a TCL of $9.5 \mathrm{~mm}$ was in the range reported by Beauchemin and Rode (1998).
However, there is limited information for expected particle size distribution for BS cut more finely, such as the 4.8-mm TCL used in the present study. Kononoff et al. (2000) reported that the pef of BS harvested at $4.8 \mathrm{~mm}$ was 0.38 , which was significantly lower than the present finding (0.68). The TCL used at harvest is not the only factor to determine particle length of silage; it is influenced by type of harvesting equipment and plant variety and maturity (Johnson et al., 2002). It can be concluded that the TCL used at harvest is not a reliable predictor of particle size distribution for BS.

The pef and peNDF content of the diets reflected the particle length of BS and was reduced with decreasing forage particle length. The peNDF values (from 10.5 to $13.8 \%$ ) of the diets in the present study were similar to those (12.4\%) reported by Eun et al. (2004), but lower than those (range of 18.9 to $21.2 \%$ ) reported by Einarson et al. (2004), probably because higher NDF (42.3\%) was formulated and the BS was cut longer (long $=19 \mathrm{~mm}$ and short $=10 \mathrm{~mm}$ ) in that study. In addition, when measured using the PSPS with 2 sieves (19 and $8 \mathrm{~mm}$ ), the pef content of barley grain-based diets is primarily 

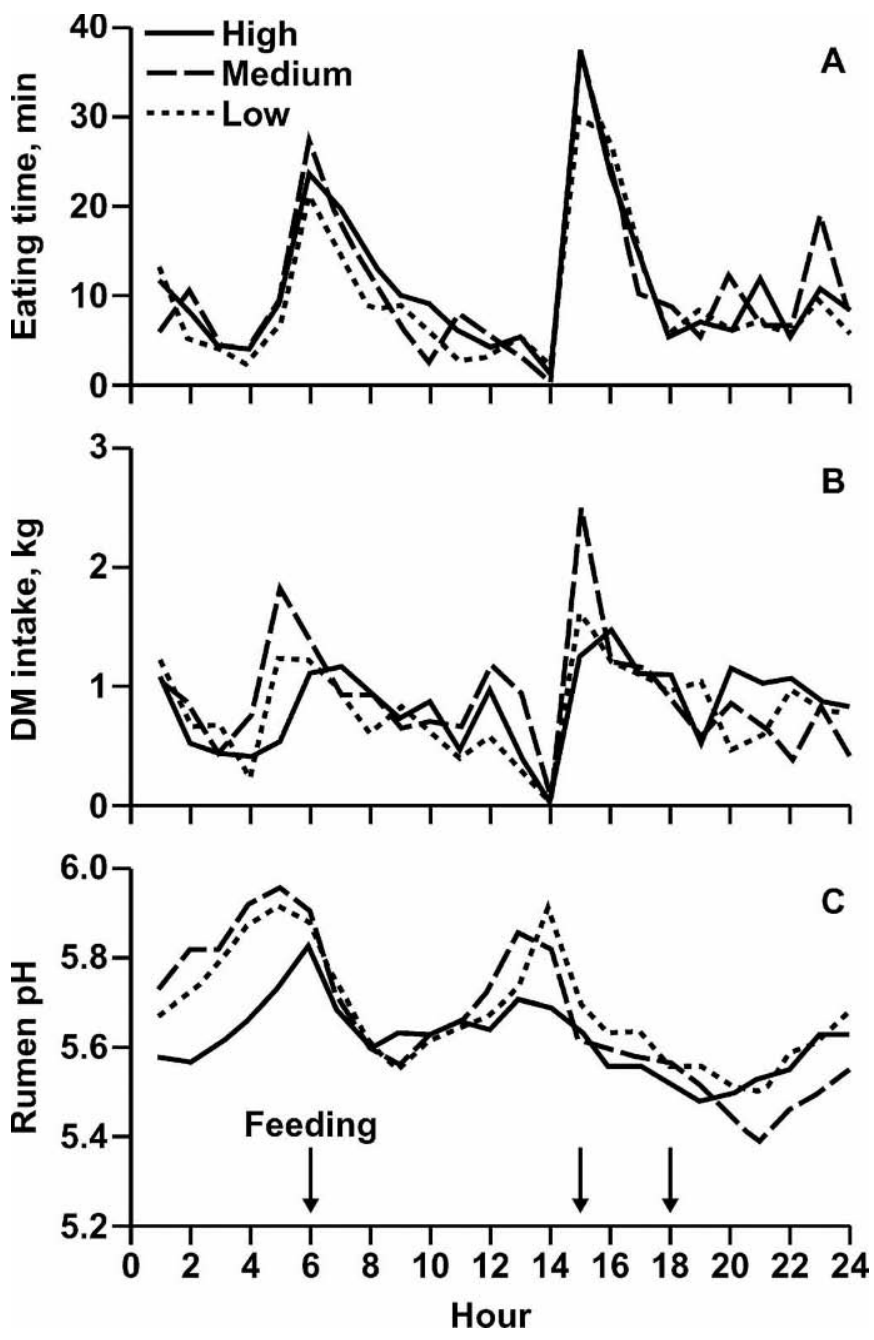

Figure 1. Effects of intake of physically effective fiber (high, medium, and low) on diurnal variation of eating time (A), amount of feed intake for each hour (B), and rumen $\mathrm{pH}(\mathrm{C})$.

dependent on the proportion of forage in the diet and its particle length because barley-based concentrates mostly pass through the $8-\mathrm{mm}$ sieve. This is confirmed by the present finding that the pef of the diets that were actually measured were similar to those estimated based on the pef of BS and the proportion of BS incorporated in the diet (measurement vs. estimation, $0.41 \mathrm{vs}$. 0.39 and 0.33 vs. 0.32 for high and low peNDF diets, respectively). Kononoff and Heinrichs (2003a) also found that the dietary pef were mainly determined by the forage portion of diets containing primarily alfalfa haylage and ground corn. However, in the study of Einarson et al. (2004), the actual measured dietary pef were greater than those estimated (measurement vs. estimation, 0.55 vs. 0.40 and 0.49 vs. 0.33 for long and short BS-based diets, respectively), indicating that a considerable amount of concentrate was retained on the $8-\mathrm{mm}$ sieve, thereby accounting for the high pef values for diets in that study. The high moisture content of BS (from 75 to $80 \%$ ) likely caused high dietary pef through adsorption of concentrate onto the wet BS (Einarson et al., 2004). In addition, Plaizier (2004) reported that about $40 \%$ of dietary pef was contributed by the concentrate portion for diets formulated with mixed forages (alfalfa silage, alfalfa hay, and corn silage). Hence, dietary pef and consequently peNDF can be extremely variable due to a number of factors such as particle size of forage and concentrate, proportion of forage in the diet, type of forage, processing of the grain, forage moisture, sieving conditions, and so on.

Sorting in favor of long feed particles, especially for the high peNDF diet, was noticeable in the present study. This observation agrees with the previous findings (Beauchemin and Yang, 2005), but contrasts with the report by Calberry et al. (2003), and Leonardi and Armentano (2003), who observed that cows actually selected against long feed particles in favor of short feed particles for alfalfa hay or alfalfa silage-based diets. Based on the results from a previous study, we suggested that dairy cows may intentionally select long feed particles to meet their need for physically effective fiber when ruminal $\mathrm{pH}$ is low due to low intake of peNDF (Beauchemin and Yang, 2005). However, compared with the current study, selection in favor of long feed particles was greater in the previous study (Beauchemin and Yang, 2005). In that study, the pef of orts $24 \mathrm{~h}$ after feeding was reduced by $40 \%$ (average pef of TMR offered vs. orts, 0.32 vs. 0.20 ) when mean ruminal $\mathrm{pH}$ was only 5.49 , whereas in the present study, the pef was reduced by $17 \%$ (Table 3) $24 \mathrm{~h}$ after feeding when mean ruminal $\mathrm{pH}$ was 5.65 . In contrast, mean ruminal $\mathrm{pH}$ were 6.36 and 6.38 , respectively, in the studies of Calberry et al. (2003) and Leonardi and Armentano (2003) in which sorting against coarser particles was observed.

Failure to observe an effect of particle length on intake of DM and NDF is in agreement with some observations (Soita et al., 2000; Beauchemin et al., 2003; Calberry et al., 2003) but in contrast to other studies in which positive effects on DMI and NDF intake from reduced particle size have been reported (Kononoff et al., 2003; Einarson et al., 2004). Dry matter intake can be regulated by many factors (Allen, 2000). For example, feed intake is reduced when dairy cows have SARA (Kleen et al., 2003) characterized by ruminal pH below 5.8. In the present study, the cows apparently experienced SARA regardless of dietary peNDF offered, because mean ruminal $\mathrm{pH}$ was below 5.8 and duration in which ruminal $\mathrm{pH}$ was below 5.8 ranged from 13 to 16 $\mathrm{h}$ over $24 \mathrm{~h}$ (Table 6). In fact, feed intake in the present 
Table 6. Effects of reducing dietary physically effective fiber (peNDF) on ruminal $\mathrm{pH}$ and fermentation characteristics of dairy cows

\begin{tabular}{|c|c|c|c|c|c|c|}
\hline \multirow[b]{2}{*}{ Item } & \multicolumn{3}{|c|}{ Dietary peNDF } & \multirow[b]{2}{*}{$\mathrm{SE}$} & \multicolumn{2}{|c|}{ Effects } \\
\hline & High & Medium & Low & & Linear & Quadratic \\
\hline \multicolumn{7}{|l|}{$\mathrm{pH}$} \\
\hline Mean & 5.62 & 5.65 & 5.68 & 0.15 & $\mathrm{NS}^{2}$ & NS \\
\hline Area under curve, $\mathrm{pH} \times \mathrm{h} / \mathrm{d}$ & 129.7 & 130.7 & 131.3 & 3.3 & NS & NS \\
\hline Area under $\mathrm{pH} 5.8, \mathrm{pH} \times \mathrm{h} / \mathrm{d}$ & 6.9 & 7.0 & 5.6 & 2.0 & NS & NS \\
\hline Area under $\mathrm{pH} 5.5, \mathrm{pH} \times \mathrm{h} / \mathrm{d}$ & 3.2 & 2.6 & 2.1 & 1.1 & NS & NS \\
\hline $\mathrm{pH}<5.8, \mathrm{~h} / \mathrm{d}$ & 13.4 & 16.7 & 13.9 & 3.1 & NS & NS \\
\hline $\mathrm{pH}<5.5, \mathrm{~h} / \mathrm{d}$ & 10.2 & 11.1 & 8.6 & 2.8 & NS & NS \\
\hline Highest & 6.34 & 6.35 & 6.35 & 0.14 & NS & NS \\
\hline Lowest & 5.15 & 5.16 & 5.24 & 0.09 & NS & NS \\
\hline \multicolumn{7}{|l|}{ VFA } \\
\hline Total, $\mathrm{m} M$ & 128.3 & 138.7 & 128.7 & 4.8 & NS & 0.06 \\
\hline Acetate (A), \% & 53.3 & 52.4 & 53.3 & 2.2 & NS & NS \\
\hline Propionate $(\mathrm{P}), \%$ & 26.9 & 23.1 & 25.8 & 1.9 & NS & NS \\
\hline Butyrate, $\%$ & 14.6 & 18.3 & 15.7 & 1.6 & NS & 0.11 \\
\hline $\mathrm{BCFA},{ }^{1} \%$ & 2.2 & 2.5 & 2.4 & 0.1 & NS & NS \\
\hline Valerate, $\%$ & 2.6 & 2.5 & 2.4 & 0.3 & 0.09 & NS \\
\hline Caproic, \% & 0.4 & 0.6 & 0.4 & 0.1 & NS & 0.01 \\
\hline $\mathrm{A}: \mathrm{P}$ & 2.1 & 2.5 & 2.2 & 0.2 & NS & NS \\
\hline $\mathrm{NH}_{3} \mathrm{~N}, \mathrm{~m} M$ & 8.5 & 11.0 & 8.8 & 1.1 & NS & 0.04 \\
\hline
\end{tabular}

${ }^{1}$ Branched-chain fatty acids (isobutyrate + isovalerate).

${ }^{2} \mathrm{NS}=P>0.15$.

study (range of 2.9 to $3.1 \%$ of BW/d) was lower than that observed in a previous experiment (from 3.3 to $3.6 \%$ of BW/d) conducted with the same dairy herd using diets containing BS and barley grain (Eun et al., 2004). There may be an interaction of diet particle size with forage-to-concentrate ratio on DMI. When high forage diets are fed to lactating dairy cows, a reduction of particle size that results in higher particulate passage rate from the rumen would allow for greater feed intake (Allen, 2000). But, for high concentrate diets $(>50 \%)$ similar to those used in the present study, a metabolic, rather than a physical, constraint on feed intake is expected to be rate limiting (Allen, 2000). However, a small increase in feed intake by reducing dietary particle size was observed for cows fed a high concentrate diet (58\%) when forage was coarse $(\mathrm{TCL}=19 \mathrm{~mm}$; Einarson et al., 2004).

Although the effect of forage particle size on chewing behavior has been substantially investigated, there is limited information for the effects of BS particle size determined using the PSPS, especially for diets containing barley grain. Increased ruminating time, thus total chewing time with increasing dietary peNDF observed in the present study was in agreement with findings of Soita et al. (2000) when BS was fed as the sole forage source. However, in the study of Soita et al. (2000), eating time, expressed either as total min or $\mathrm{min} / \mathrm{kg}$ of DMI, was also increased with increasing BS particle size, possibly due to greater differences between the long $(18.8 \mathrm{~mm})$ and the short $(4.7 \mathrm{~mm}) \mathrm{BS}$ used. When considering both the number of chews and chewing time, our results were similar to those of Kononoff and Heinrichs (2003b) in which number of chews (eating and ruminating) were not affected, but ruminating time per kilogram of NDF increased with increasing particle size of corn silage. In contrast, Beauchemin and Yang (2005) reported that although eating time $(\mathrm{min} / \mathrm{kg}$ of DM) was similar, number of chews per kilogram of DMI during the eating period was linearly increased $(P<0.10)$ with increasing dietary peNDF. The chewing rate (chews/min) was linearly increased from 54.4 to 58.2 and then 61.9 for fine, medium, and long silages, respectively. The authors suggested that cows could efficiently reduce long particles by increasing chewing rate (i.e., chews/min) during the eating period. For example, Fischer et al. (1994) demonstrated that chewing time per unit of feed intake was not different, but number of chews increased from 18,913 to 23,000/ d or from 757 to $987 / \mathrm{kg}$ of DMI, respectively, with increasing particle size of alfalfa silage. Brouk and Belyea (1993) also observed that chewing (eating and ruminating) time was similar, but chewing rate (chews/kg of DMI) was higher for cows fed long vs. chopped alfalfa hay. Other researchers reported both increased chewing rate and chewing time with increasing forage particle size (Kononoff and Heinrichs, 2003a). Therefore, it is likely that cows increase their chewing activity through either chewing rate or chewing time, or both, in relation to increased peNDF intake.

Increased total chewing time due to increased dietary peNDF resulted from increased ruminating time rather than increased eating time in the present study. In a 
similar manner, Kononoff and Heinrichs (2003b) and Kononoff et al. (2003) reported that only ruminating time, and consequently total chewing time (expressed as $\mathrm{min} / \mathrm{kg}$ of NDF intake) was increased $(P<0.10)$ by peNDF level when corn silage was fed as the sole forage for diets with peNDF ranging from 16 to $22 \%$ of DM. However, this is somewhat different than other reports. Soita et al. (2000) observed that both eating and ruminating time increased with increasing peNDF from 13.7 to $17.2 \%$ attained by replacing short $(4.7 \mathrm{~mm})$ with long $(18.8 \mathrm{~mm}) \mathrm{BS}$. A linear increase in eating and ruminating time with increasing dietary peNDF from 10.1 to 12.0 to 13.3 to $15.2 \%$ of DM for cows fed alfalfa silage based-diets (Kononoff and Heinrichs, 2003a), or with increasing dietary peNDF from 8.9 to 10.3 to $11.5 \%$ of DM for cows fed corn silage-based diets (Beauchemin and Yang, 2005) was observed. One can conclude from the literature that intake of peNDF based on measurements using the PSPS effectively stimulates chewing activity. However, the increase in chewing time can be the result of increased ruminating activity alone or a combination of increased ruminating and eating time. De Boever et al. (1993) reported that eating time was decreased when the TCL of corn silage was decreased from 16 to $8 \mathrm{~mm}$, whereas ruminating time was decreased when the TCL of corn silage was decreased from 8 to $4 \mathrm{~mm}$. This is confirmed by the present finding that ruminating time was decreased as the TCL of BS was decreased from 9.5 to $4.8 \mathrm{~mm}$, and also somewhat by other studies (Soita et al., 2000; Kononoff and Heinrichs, 2003a), in which both eating and ruminating activities were reduced due to decreasing TCL of forages from 20 to $4 \mathrm{~mm}$. In contrast, eating time was not affected in some studies (Kononoff and Heinrichs, 2003b; Kononoff et al., 2003) even though the TCL of corn silage was reduced from 22.3 to $4.8 \mathrm{~mm}$. In our study, the largest decrease in ruminating time was observed between the medium peNDF and low peNDF diets, which supports the suggestion of Allen (1997) that the most dramatic reductions of chewing occur when particle size is reduced below $3 \mathrm{~mm}$.

Failure to obtain a direct relationship between peNDF level and eating and ruminating time may be partially explained by several potential errors in the estimation of dietary peNDF contents, peNDF intake, and chewing activity. Firstly, dietary peNDF estimation based on pef and dietary NDF content may not be consistently estimated among studies due to substantial variation of pef measurement as discussed previously. Dietary particle distribution may be different for feeds with the same peNDF level. For example, even though the dietary peNDF levels used in this study were similar to those used by Kononoff and Heinrichs (2003a), the proportion of particles retained on the 19- $\mathrm{mm}$ sieve was significantly lower in our study. Particles on the 19 -mm sieve stimulate chewing activity in dairy cattle, shown using alfalfa silage (Kononoff and Heinrichs, 2003a) and corn silage (Kononoff et al., 2003). In this study, there was a weak correlation $(\mathrm{r}=0.36, P<$ 0.15 ) for particles on the $19-\mathrm{mm}$ sieve and ruminating chews/d or ruminating time/d (Table 7). Secondly, sorting in favor of long particles (Table 3) or against long particles (Calberry et al., 2003) would substantially change the actual intake of peNDF from that expected, and this source of variation is not corrected for in some studies. Finally, the peNDF may affect chewing activity through either prolonging chewing time or increasing chewing rate, which is often not measured. In fact, a moderate correlation of intake of dietary peNDF with eating chews $(\mathrm{r}=0.54, P<0.05)$ or ruminating chews ( $\mathrm{r}=0.63, P<0.01$ ) was observed (Beauchemin and Yang, 2005).

Lack of effect of BS particle size on ruminal $\mathrm{pH}$ in the present study contrasts with the commonly accepted principle that increasing particle length promotes chewing activity, and thus increases buffering capacity within the rumen due to increased saliva secretion. Although that concept is supported by a number of studies (Krause et al., 2002; Beauchemin et al., 2003), it is not always the case (Kononoff and Heinrichs, 2003b; Plaizier, 2004; Beauchemin and Yang, 2005). It is clear that increased peNDF intake increases chewing time, but whether increased chewing time results in improved ruminal $\mathrm{pH}$ may depend upon a number of factors. Firstly, the effects of peNDF on increasing chewing time are greatest for finely chopped diets, for which ruminal $\mathrm{pH}$ is low. The increase in salivary buffering capacity may be insufficient to increase ruminal $\mathrm{pH}$ when $\mathrm{pH}$ is below 6 . Fermentability of feeds is critical in the regulation of ruminal $\mathrm{pH}$, as ruminal $\mathrm{pH}$ is a balance between fermentation acid production and acid removal (absorption and neutralization). The peNDF does not account for differences in fermentability of feeds, and does not predict differences in chewing and ruminal $\mathrm{pH}$ due to grain fermentability. In a study by Yang et al. (2001) to investigate the effects of grain processing, fiber content, and forage particle size on ruminal $\mathrm{pH}$ and digestion, ruminal $\mathrm{pH}$ was significantly affected by grain processing but not by peNDF. Higher fermentability of barley grain compared with corn could be another factor accounting for the low ruminal $\mathrm{pH}$ in the present study. Secondly, intrinsic buffering capacity of forages affects rumen buffering. Corn silage has a lower intrinsic buffering capacity than alfalfa silage (McBurney et al., 1983), and consequently there is often no effect of dietary particle size on ruminal $\mathrm{pH}$ observed for corn silage-based diets. Finally, the 
Table 7. Pearson correlation coefficients ${ }^{1}$ between dietary particle size distribution or peNDF ${ }^{2}$ proportion (\% of $\mathrm{DM}$ ) and eating patterns, chewing behavior, and ruminal $\mathrm{pH}$

\begin{tabular}{|c|c|c|c|c|c|}
\hline \multirow[b]{2}{*}{ Variables } & \multicolumn{3}{|c|}{ Dietary particle length (\% of DM) } & \multirow[b]{2}{*}{ pef } & \multirow[b]{2}{*}{ peNDF } \\
\hline & $>19 \mathrm{~mm}$ & $>8 \mathrm{~mm}$ & $>8 \mathrm{~mm}$ & & \\
\hline Meals/d & 0.14 & 0.19 & -0.19 & 0.19 & 0.22 \\
\hline Meal length, min & -0.06 & 0.14 & -0.11 & 0.11 & 0.05 \\
\hline Intake rate, $\mathrm{g}$ of $\mathrm{DM} / \mathrm{min}$ & -0.02 & -0.35 & 0.30 & -0.30 & -0.23 \\
\hline Eating chews/d & 0.04 & 0.23 & -0.21 & 0.21 & 0.16 \\
\hline Eating time, $\mathrm{min} / \mathrm{d}$ & 0.04 & 0.23 & -0.21 & 0.21 & 0.16 \\
\hline Ruminating chews/d & 0.36 & 0.34 & -0.35 & 0.35 & 0.26 \\
\hline Ruminating time, $\mathrm{min} / \mathrm{d}$ & 0.36 & 0.34 & -0.35 & 0.35 & 0.26 \\
\hline Total chewing time, $\mathrm{min} / \mathrm{d}$ & 0.27 & 0.34 & -0.34 & 0.34 & 0.26 \\
\hline Rumen $\mathrm{pH}$ mean & 0.04 & 0.02 & 0.01 & 0.01 & -0.18 \\
\hline Rumen $\mathrm{pH}<5.8, \mathrm{~h} / \mathrm{d}$ & 0.03 & 0.01 & 0.01 & 0.01 & 0.14 \\
\hline Rumen $\mathrm{pH}<5.5, \mathrm{~h} / \mathrm{d}$ & 0.08 & 0.10 & -0.11 & 0.11 & 0.26 \\
\hline Area under $\mathrm{pH} 5.8, \mathrm{pH} \times \mathrm{h} / \mathrm{d}$ & 0.09 & 0.11 & -0.11 & 0.11 & 0.30 \\
\hline Area under $\mathrm{pH} 5.5, \mathrm{pH} \times \mathrm{h} / \mathrm{d}$ & 0.13 & 0.15 & -0.15 & 0.15 & 0.35 \\
\hline Rumen VFA, $\mathrm{m} M$ & 0.01 & -0.04 & 0.03 & -0.03 & 0.01 \\
\hline
\end{tabular}

${ }^{1}$ Correlation coefficients were significant at $P<0.01$ ( $>0.59$ or $\left.<-0.59\right), P<0.05(>0.47$ or $<-0.47$ ), and $P<0.15$ ( $>0.36$ or $<-0.36)$.

${ }^{2}$ Particle size distribution was determined using the Penn State Particle Separator (PSPS), physical effectiveness factor (pef) determined as the proportion of particles (DM basis) retained by both sieves of the PSPS, and physically effective NDF (peNDF) estimated as the NDF content of the TMR multiplied by pef. Particle size distributions were adjusted for particle size of orts.

method used for measuring ruminal $\mathrm{pH}$ could be another factor influencing the results. Mean ruminal $\mathrm{pH}$ determined from a series of ruminal samples does not reflect the diurnal fluctuations in ruminal $\mathrm{pH}$ for individual cows. Beauchemin et al. (2003) reported that when $\mathrm{pH}$ was measured using continuous indwelling electrodes, decreased alfalfa particle size reduced mean $\mathrm{pH}$ by only $4 \%$, but the area of the curve under $\mathrm{pH} 5.8$ or duration of $\mathrm{pH}<5.8$ was almost tripled or doubled, respectively.

\section{CONCLUSIONS}

Increasing the chop length of barley silage increased the intake of physically effective fiber and increased chewing activity due to increased ruminating time without affecting eating time of dairy cows. However, increased chewing activity did not improve ruminal $\mathrm{pH}$ status, or decrease the incidence of subclinical acidosis. Although increasing forage particle size increased rumination, the incremental increase in fermentation acids produced in the rumen as a result of increased ruminal digestion balanced the incremental buffering capacity resulting from increased salivation. Low physically effective fiber content of diets containing a highly fermentable carbohydrate source, such as barley grain, caused low ruminal $\mathrm{pH}$, which was not increased by increasing particle size of the forage.

The Penn State Particle Separator is a useful device that can be used on the farm to measure particle size of forages and TMR. The physically effective fiber is a good indication of the rumination potential of the feed.

\section{ACKNOWLEDGMENTS}

This experiment was financially supported by the Dairy Farmers of Canada (Ottawa, ON) and Agriculture and Agri-Food Canada's Matching Investment Initiative. The authors thank K. Andrews, B. Farr, D. Vedres, and R. Wuerfel for their assistance in performing sampling, ruminal $\mathrm{pH}$ and chewing measurements, and laboratory analyses, and as well as the staff of the Lethbridge Research Centre dairy unit for care of the cows and milk sample collection.

\section{REFERENCES}

Allen, M. S. 1997. Relationship between fermentation acid production in the rumen and the requirement for physically effective fiber. J. Dairy Sci. 80:1447-1462.

Allen, M. S. 2000. Effects of diet on short-term regulation of feed intake by lactating dairy cattle. J. Dairy Sci. 83:1598-1624.

AOAC. 1990. Official Methods of Analysis. Vol. I. 15th ed. Association of Official Analytical Chemists, Arlington, VA.

Beauchemin, K. A. 2000. Managing rumen fermentation in barley based diets: Balance between high production and acidosis. Adv. Dairy Technol. 12:109-125.

Beauchemin, K. A., and L. M. Rode. 1998. Effective fibre in barleybased diets. Adv. Dairy Technol. 10:151-165.

Beauchemin, K. A., and W. Z. Yang. 2005. Effects of physically effective fiber on intake, chewing activity, and ruminal acidosis for dairy cows fed diets based on corn silage. J. Dairy Sci. 88:2117-2129.

Beauchemin, K. A., W. Z. Yang, and L. M. Rode. 2003. Effects of particle size of alfalfa-based dairy cow diets on chewing activity, rumen fermentation, and milk production. J. Dairy Sci. 86:630-643.

Brouk, M., and R. Belyea. 1993. Chewing activity and digestive responses of cows fed alfalfa forages. J. Dairy Sci. 76:175-182.

Calberry, J. M., J. C. Plaizier, M. S. Einarson, and B. W. McBride. 2003. Effects of replacing chopped alfalfa hay with alfalfa silage 
in a total mixed ration on production and rumen conditions of lactating dairy cows. J. Dairy Sci. 86:3611-3619.

De Boever, J. L., D. L. De Brabander, A. M. DeSmet, J. M. Vanacker, and C. V. Boucque. 1993. Evaluation of physical structure. 2. Maize silage. J. Dairy Sci. 76:1624-1634.

DeVries, T. J., M. A. G. von Keyserlingk, D. M. Weary, and K. A. Beauchemin. 2003. Measuring the feeding behavior of lactating dairy cows in early to peak lactation. J. Dairy Sci. 86:3354-3361.

Einarson, M. S., J. C. Plaizier, and K. M. Wittenberg. 2004. Effects of barley silage chop length on productivity and rumen conditions of lactating dairy cows fed a total mixed ration. J. Dairy Sci. 87:2987-2996.

Eun, J.-S., K. A. Beauchemin, S.-H. Hong, and W. Z. Yang. 2004. Effects of mechanical processing on the nutritive value of barley silage for lactating dairy cows. J. Dairy Sci. 87:4170-4177.

Fischer, J. M., J. G. Buchanan, C. Campbell, D. G. Grieve, and O. B. Allen. 1994. Effects of forage particle size and long hay for cows fed total mixed rations based on alfalfa and corn. J. Dairy Sci. 77:217-229.

Johnson, L., J. H. Harrison, D. Davidson, J. Robutti, M. Swift, B. Mahanna, and K. Shinners. 2002. Corn silage management I. Effects of hybrid, maturity, mechanical processing, on chemical and physical characteristics. J. Dairy Sci. 85:833-853.

Kleen, J. L., G. A. Hooijier, J. Rehage, and J. P. Noordhuizen. 2003. Subcute ruminal acidosis (SARA): A review. J. Vet. Med. A Physiol. Pathol. Clin. Med. 50:406-414.

Kononoff, P. J., and A. J. Heinrichs. 2003a. The effect of reducing alfalfa haylage particle size on cows in early lactation. J. Dairy Sci. 86:1445-1457.

Kononoff, P. J., and A. J. Heinrichs. 2003b. The effect of corn silage particle size and cottonseed hulls on cows in early lactation. J. Dairy Sci. 86:2438-2451.

Kononoff, P. J., A. J. Heinrichs, and H. A. Lehman. 2003. The effect of corn silage particle size on eating behavior, chewing activities, and rumen fermentation in lactating dairy cows. J. Dairy Sci. 86:3343-3353.

Kononoff, P. J., A. F. Mustafa, D. A. Christensen, and J. J. McKinnon. 2000. Effects of barley silage particle length and effective fiber on yield and composition of milk from dairy cows. Can. J. Anim. Sci. 80:749-752.

Krause, K. M., D. K. Combs, and K. A. Beauchemin. 2002. Effects of forage particle size and grain fermentability in midlactation cows. II. Ruminal pH and chewing activity. J. Dairy Sci. 85:1947-1957.

Lammers, B. P., D. R. Buckmaster, and A. J. Heinrichs. 1996. A simple method for the analysis of particle sizes of forage and total mixed rations. J. Dairy Sci. 79:922-928.
Leonardi, C., and L. E. Armentano. 2003. Effect of quantity, quality, and length of alfalfa hay on selective consumption by dairy cows. J. Dairy Sci. 86:557-564.

Maekawa, M., K. A. Beauchemin, and D. A. Christensen. 2002. Effect of concentrate level and feeding management on chewing activities, saliva secretion, and ruminal $\mathrm{pH}$ of lactating dairy cows. J. Dairy Sci. 85:1165-1175.

McBurney, M. I., P. J. Van Soest, and L. E. Chase. 1983. Cation exchange capacity and buffering capacity of neutral detergent fibres. J. Sci. Food Agric. 34:910-916.

Mertens, D. R. 1997. Creating a system for meeting the fiber requirements of dairy cows. J. Dairy Sci. 80:1463-1481.

National Research Council. 2001. Nutrient Requirements of Dairy Cattle. 7th rev. ed. Natl. Acad. Sci., Washington, DC.

Nocek, J. E. 1997. Bovine acidosis: Implication on laminitis. J. Dairy Sci. 80:1005-1028.

Plaizier, J. C. 2004. Replacing chopped alfalfa hay with alfalfa silage in barley grain and alfalfa-based total mixed rations for lactating dairy cows. J. Dairy Sci. 87:2495-2505.

Rode, L. M., W. Z. Yang, and K. A. Beauchemin. 1999. Fibrolytic enzyme supplements for dairy cows in early lactation. J. Dairy Sci. 82:2121-2126.

Russell, J. B., and D. B. Wilson. 1996. Why are ruminal cellulolytic bacteria unable to digest cellulose at low $\mathrm{pH}$ ? J. Dairy Sci. 79:1503-1509.

SAS Institute. 1996. SAS7 User's Guide: Statistics, Version 7 ed. SAS Institute, Inc., Cary, NC.

Soita, H. W., D. A. Christensen, and J. J. McKinnon. 2000. Influence of particle size on the effectiveness of the fiber in barley silage. J. Dairy Sci. 83:2295-2300.

Van Soest, P. J., J. B. Robertson, and B. A. Lewis. 1991. Methods for dietary fiber, neutral detergent fiber and non-starch polysaccharide in relation to animal nutrition. J. Dairy Sci. 74:35833597.

Weatherburn, M. W. 1967. Phenol-hypochlorite reaction for determination of ammonia. Anal. Chem. 39:971-974.

Yang, W. Z., K. A. Beauchemin, B. Farr, and L. M. Rode. 1997. Comparison of hull-less barley, barley or corn for lactating cows: Effects on extent of digestion and milk production. J. Dairy Sci. 80:2475-2486.

Yang, W. Z., K. A. Beauchemin, and L. M. Rode. 2001. Effects of grain processing, forage to concentrate ratio, and forage particle size on rumen $\mathrm{pH}$ and digestion by dairy cows. J. Dairy Sci. 84:2203-2216. 